\title{
Academic and Social Challenges Faced by African International Students in Collegiate institutions in America
} Gbenga Samuel Okusolubo*

School of Graduate and Professional Studies, Central Penn College, 600 Valley Rd, Summerdale, PA 17093, USA

\begin{abstract}
International students' enrollment in higher education in the U.S has expanded considerably in the last decades In 2015, the United States hosted more of the world's 4.1 million international students than any other country (Institute for International Education, 2015). With the number of foreign students that come to study in the U.S, $14.5 \%$ of international students are African students with the majority of the population coming from Nigeria, Kenya and Ghana. The U.S. is often described as the land of opportunity abroad, but this research intends to explore that perception for international students, especially African students. Many consider African international students as the gateway to local business owners in the U.S seeking to expand a wider global horizon, especially in Africa. This research explored the different types of academic and social challenges faced by African international students in collegiate institutions in America through auto-ethnographic research, and to find possible solutions to those challenges faced by African students. This is a qualitative research approach that used the sequential autoethnographic experience of the author as the research tool in identifying and categorizing some of the challenges faced by African international students. It is the researcher's intention that the findings in this research will be used as a guide for the next group of African international students aspiring to come to the U.S to study.
\end{abstract}

Keywords: African international student; Challenges; Possible solutions; Auto-ethnography

\section{Introduction}

Our journey in search of academic knowledge and literacy started as a dream. In fact, it seems like every African icon that we know started their journey to excellence with a dream. Much has been said about Nelson Mandela. His dream to free South Africans from the apartheid colonial masters started from prison. Kofi Annan; the first black African to become United Nations secretary general, Trevor Noah; the first African immigrant to host a major talk show program in America, Wole Shoyinka; first black African person to win the Nobel Prize for Literature, all have dreaming in common. As a kid, we always joked with our mother that God made a mistake of sending me to Africa. She would laugh and ask, "Son, where do you think God intended to send you to in the first place?" With joy, unspeakable, we would always respond by saying, "to the white man land". Like every African child raised on the dusty streets and stinky swamps of Africa, we dream big and usually, those dreams are quite bigger than who we are as an individual. When we told our parents that we wanted to go to America to study, it sparked mixed feelings in them. We could see the happiness of a father about his son aspiring to be great in life and almost immediately, we could see his worst nightmare and fear of how to afford the cost of transitioning from Nigeria to America; and paying for tuition. We graduated secondary school and applied to as many universities in the U.S. as possible. Eventually, we had to come to the reality that the only way we could travel abroad to study was if our family sold everything we worked for over the years. We could not come to accept the idea of seeing family go back to abject poverty after years of struggles to be an average income earning family. We were left with no other option than to go for the universities we had in our country, where we eventually achieved bachelor's degree. After years of obtaining academic knowledge at the undergraduate level, we finally decide to proceed for graduate degree program in America.

Upon arrival in America as an international student from Africa, we realized that universities and colleges rely heavily on international students for income and as resources in the form of cultural diversity, intellectual diversity and academic diversity. Since the beginning of civilization, man has traveled to far-flung places to quench his thirst for knowledge and comprehension. With the invention of planes and high-speed trains, traveling has become so easy that the number of international students seeking education in foreign countries, like America, has grown significantly. The main goal of international students is the attainment of higher education in a foreign country, which often provides a higher quality education compared to what can be obtained in their country of origin. In America, international students are regarded as academic and knowledge seeking nationals who cross borders for the purpose of studying at any American collegiate institution, with a 'student' visa, as defined by the Immigration Control and Refugee Recognition Act. In 2015, the continued growth in international students coming to the U.S. for higher education had a significant positive economic impact on the United States. International students contributed more than $\$ 30.5$ billion to the U.S. economy, according to the U.S. Department of Commerce.

The number of international students coming to study in the U.S has increased over the years. Presently, most international students in America are Asian (61\%), while African students are said to be 14.5 percent. According to the Open Doors Report published by the Institute of International Education (2015), the 2014-2015 school year in the U.S. saw a 7\% increase in African international students. The United States is considered by many international students as the land of opportunity flowing with milk and honey. According to

*Corresponding author: Gbenga Samuel Okusolubo, School of Graduate and Professional Studies, Central Penn College, 600 Valley Rd, Summerdale, PA 17093, USA, Tel: 17093-0309; E-mail: olatovas445@gmail.com

Received February 23, 2018; Accepted March 29, 2018; Published April 06, 2018

Citation: Okusolubo GS (2018) Academic and Social Challenges Faced by African International Students in Collegiate institutions in America. Int J Econ Manag Sci 7: 514. doi: 10.4172/2162-6359.1000514

Copyright: $\odot 2018$ Okusolubo GS. This is an open-access article distributed under the terms of the Creative Commons Attribution License, which permits unrestricted use, distribution, and reproduction in any medium, provided the original author and source are credited. 
the survey conducted by the Institute of International Education (IIE 2016), the majority of African international students come from the sub-Saharan region of the continent, which includes: Nigeria, Kenya, Ghana, Cameroon and South Africa. NAFSA's latest analysis shows that 48,000 jobs added to the U.S economy between 2015-2016 were credited to African international students. With the increased numbers of African students trooping to America like ourselves, their story for survival and keeping their academic dreams alive supports that it's never been an easy task. Many African students journey to America in search of academic knowledge and a better life and as an African international student from a remote town in Nigeria and one of the dusty streets in Africa, we realize that there are lots of challenges African international students are facing and a series of hurdles that needed to be jumped. Regardless of the struggles and challenges faced by African international students, studies and research have shown that African international students are some of the most highly educated immigrants in the United States.

This purpose of this research is to explore and identify the different types of social and academic challenges faced by this unique group of African international students. Another aim of this research study is to identify and provide possible recommendations and solutions to both social and academic challenges faced by African international students in collegiate institutions in America. While much research has been done concerning international students, major challenges faced by African international students is not common in academic literature and therefore, little or no effort has been made to provide concrete and substantial solutions to these challenges. The social and academic challenges faced by African international students in America range from stereotyping, racism, culture shock, difference in academic curriculum, language and many more. This research study attempts to provide solutions that can help African international students integrate into their new American environment both socially and academically.

Most academic and social challenges every African international student faces, or is currently facing, are unique and more intense because of the added pressure of adjusting to a new culture, language, and different academic environment. In spite of these challenges, African students increase the diversity of student populations, add new perspectives to classroom discussions, increase awareness and appreciation for other countries and cultures, and arrive with knowledge and skills, especially in the sciences. Colonization is one of the major factors why African international students are now having major challenges in their academics. In a study on the effects of colonization on the career choices of African students in the United States, Bessong \& Traore found that colonization has a negative effect on the career choices and occupational decisions of these students. Language is a vital tool in passing information or commands from an instructor to the learner. The language of instruction and academic structures in most African academic institutions are usually the language of the colonizer, which are often not English. This has a major effect on African international students in America where they have to deal with English as a second language and require added academic support. However, this disadvantage is offset by the several advantages to having African students in the American universities and colleges.

"Over the past decades, the population of international students enrolled in universities of the United States has been increasing, deserving special attention to meet their academic and social needs" says Contreras-Aguirre \& Gonzalez. As the numbers of international students continues to increase, so does the number of African international students coming to America to study. Because of the unique characteristics international students and African students bring along with them to America, these students population enriches colleges and universities environment, adds value in terms of diversity, and asks for a better understanding from American students, staff, and faculty. In addition, international students are valuable economic and financial assets to the American collegiate institutions and to the U.S. economy. African international students have proven over the years to have contributed positively to the U.S. economy in the form of intellectual diversity. According to the latest analysis published by the Institute of International Education (2015), African international students are considered to be the most highly educated immigrants in the United States. NAFSA statistical analysis also shows that more than $43 \%$ of African immigrants, which includes African immigrant and refugee students, have at least a Bachelor's degree or higher. This indicates that African international students are both intellectual and cultural assets to American universities and colleges.

As an African international student in America, academic and social difficulties have been two major concerns for any African international students. Academic challenges faced by international students originate from differences in educational systems, language proficiency, and cultural differences relative to classroom atmosphere and faculty-student rapport. Academically, most African students have been trained to listen rather than talk or participate in classroom discussion without permission. African international students grow up learning through commands and imitation compared to the academic learning style in America that embraces questioning and classroom participation. In African educational experience, most of the academic tests and exams we have taken are usually essay questions at the end of the semester compared to the system of education in America, where frequent multiple-choice, class participation, online discussion board and short-essay examinations are used to test a student's critical thinking ability in a short period of time. These differences in testtaking techniques, course structure, course content, and academic standards have resulted in stressful academic difficulties for African international students.

Cultural differences present very real personal and professional challenges in academics for African international students. Because of the language limitations, it is not easy for an African international student to fully understand what the professors say or what the professors want in assignments from each student, not to mention participating in class discussions. The language problem could also indirectly increase the workload burden of international students. If an American student can finish a book in an hour, an African international student who does not speak English at home may have to consume three hours to finish the same reading. Some African international students are academic stars in their home country, and it becomes a challenge when they are no longer the superior student in a foreign university. In fact, it is easy for international students to get depressed when they are no longer keeping the grades they are used to achieving.

Socially, African international students have trouble adapting to their new environment and culture. African students often arrive in the United States with certain expectations and hopes about their social life but quickly discover upon arrival the difference between their social expectations and the social reality of life. The difference in an African international student's social expectation and reality upon arrival in America often results in a profound sense of loss, isolation, alienation, and loneliness that, in turn, results in losing self-confidence, gaining tension, working harder than usual, and taking little time off for leisure. In many situations, African international students are prone 
to facing a series of social barriers. Intellectually, African international students often face discrimination as one of the social challenges in the way Americans perceive themselves to be intellectually superior to people from other countries, especially Africa. African international students are treated as uninvited guests by some local students who are resentful because they believe international students are taking away their opportunities [1]. On many occasions, African international students are subjected to racism, discrimination, and stereotyping which is a social concern for them to face in small numbers. Most African international students are members of a majority group in their countries; adapting to minority status is difficult upon their arrival to America. Evivie noted that African international students also experience verbal discrimination and segregation when faculty, advisors, or local community members make negative comments about their home countries or culture.

According to Traoré [2], "...negative stereotypes about Africa abound in American schools and in the media, making it virtually impossible for newly arrived African students, whether immigrants or refugees, to accomplish their goals of getting a quality education". On arrival, African international students immediately confront social barriers and difficulties that take the form of negative myths, stereotypes, and misperceptions that Americans have about Africans [3]. In some cases, local students stereotype African international students based on the information they get from their local news channel or media. Familiar images such as the Lion King and Tarzan swinging from one tree to the other in the jungle start with children. Wild animal poaching, wars, disease and starving people with AIDS are some of the media images shaping American students' understanding and conception of African international students. Evivie noted the media (e.g., televised charities such as Save the Children and Christian Children's Fund as well as the Discovery Channel and National Geographic), and the curriculum in school, and the home environment of their fellow students perpetuate these myths, stereotypes, and misperceptions. Furthermore, these African immigrant and refugee students, due to the color of their skin, are faced with the same legacy of prejudice endured by African Americans.

"Auto-ethnography is an approach to research and writing that seeks to describe and systematically analyze (graphy) personal experience (auto) in order to understand cultural experience (ethno)" [4]. Using auto-ethnography as the research tool for this study, we reflect on the series of experiences we had lived through since, arrived in the United States of America in 2016 - to the date of this research. These experiences have in one way or the other made a major impact on academic and social life. Auto-ethnography is an intriguing and promising qualitative method for study. As defined by Ellis and Bochner, "auto-ethnography is an autobiographical genre of writing and research that displays multiple layers of consciousness, connecting the personal to the cultural" (p. 739). To me, everything about this study was a personal experience we lived through. We had no way of detaching ourselves from what had been our lived experiences of over a year, so instead of attempting objectivity, we chose to embrace subjectivity and use our personal voice to speak to the reader. Autoethnography is a qualitative research method that utilizes data about self and its context to gain an understanding of the connectivity between self and others within the same context. This research method is also distinctive from others in three ways: it is qualitative, selffocused, and context-conscious. "Autoethnographic data provide the researcher a window through which the external world is understood". In this study, we used our auto-ethnographic experience towards data collection, analysis, and interpretation about academic and social challenges involving our personal academic journey in America.

Auto-ethnographers pay varying levels of attention to narration/ description and analysis/interpretation of autobiographical data. Personally, we decided to adopt a blended approach from autoethnographic experience (self-reflection tool) and volunteered to share our participant observations with five different African international students to see if experiences were unique. By sharing one's own lived experience with other participant observers, we set out to identify those common academic and social challenges faced by African international students in the United States.

\section{Participant Observation}

Participant observation is regarded as a "strategic" method of cultural anthropology. Participant observation involves spending time in the company and personally experiencing the lives of the studied people. The five African international students from five different African countries; Nigeria, Kenya, Ghana, Cameroon and South Africa voluntarily offered to proof read this study, add their voice and participate in the process of quality for the research findings. With their reviewing, the researcher's continued personal observation alongside informants in everyday situations noted in this research - it makes it possible to collect more and higher-quality data, as it reduces the "problem of reactivity - of people changing their behavior when they know they are being studied". Conquer good reminded us that "auto-ethnography is an embodied practice," of which "the embodied researcher is the instrument". In this sense, it is important to recognize that, in many ways, we had been collecting data informally for this project ever since we stepped off the plane that brought me to the United States; we just wasn't aware of it at the time. From February 2016 to the present, we experienced what it has meant to be an African international student at a collegiate institution in America. We decided to use participant observations in this study to achieve credibility that goes beyond individual truth to a more inclusive, collective truth about research findings.

Finally, we compiled suggestions from other participants on identified academic and social challenges faced by African international students. Based on the participant suggestions and perspective as an African international student, as part of this research structured a set of possible solutions that can help improve an African student's academic success and improve their social experience in their different collegiate institutions. This study gave a voice to African international students by providing information that enhances an understanding of the challenges that impede both the social and academic success and the possible solutions that can be used to overcome these challenges. These findings will be useful to students, faculty, the collegiate community at large, international agencies concerned with the state of higher education in Africa and the aspiring African international student aiming to study in America.

The social and academic challenges African international students encounter in America come in different forms and shapes. From our experience, the difficult journey of the academic challenges we faced in America began long before we left Africa and continue to this day.

\section{Immigration and Visa}

Our academic journey to America began with an immigration and visa application. As suggested by Lee and Rice, we found the process of dealing with immigration and securing an F1 international student visa 
to be challenging. In our experience as an African international student, immigration was one of the challenges. Legal issues like immigration and securing an F1 visa does not start in America, the battle to secure an American student visa starts from the individual African students' homeland country. Since the September $11^{\text {th }}$ terrorist attacks, coming to the United States to study for African immigrant or refugee students has become rigorous and strenuous. For a visa applicant like us to have the chance of walking into the American consulate office to apply for a student visa, there are prior requirements and conditions we had to meet. As an African student, before we were accepted into any school in America, we would have to not only proved academic ability and intent, but also our financial competence. Acceptance into a collegiate institution is not a gateway to securing a visa at the embassy. We were made to understand this concept when we were applying for a student visa. With the immigration process, we were asked to provide supporting documents to show proof of financial support and other necessary documents that improved chances of getting a visa. Consider moving the Financial Pressure section here next. You set up the introduction for it.

\section{Academic requirements and expectations}

In the beginning of academic journey in America, we were very excited at the prospect of learning opportunities for gaining knowledge and developing relevant skills via technology (e.g. computers) and the library (e.g., books and research tools). But upon arrival in America, as African international student, the immediate academic challenges we faced with left us, realizing that academic support services did not adequately cater to our challenges with admission, registration, and residence life. Academic beginnings suffered a setback during the first semester because of a rule and regulation mandating that every international student aiming to study at a master's level must have an evaluation of their bachelor's degree transcript unless it is from an accepted United States college. This was a strange situation for us as we often debated with our college cultural diversity officer that every detail needed by the school was right there on academic transcript and we were surely not the first African to come from Olabisi Onabanjo University to America to study. Having to wait a whole semester to evaluate our transcripts while we watched other Master's students was a hardship for us as we were spending valuable time and money without achieving our goal of an education.

Once accepted into the Master's program, some college academic courses required online classes which then posed an immediate academic problem for an African student like me that has never experienced any online lecture or classes. For most African students, having an online class can best be termed as mysterious. What is online class we asked? How do we get online for these mysterious classes, we wondered? How do we respond in an online class? These were typical questions we rained down on the college diversity officer, the graduate program coordinator and many on ground instructors. The truth is we had never experienced studying online due to lack of technological infrastructure in our prior education back in Africa.

During our bachelor's degree, the only way we learned to solve an assignment was to Google the question, patch any answer seen online with a bit of our opinion and pour it back to the lecturer who administered the assignment. It was a simple game of what you give me as the teacher is what you got back. African students are not taught about critical thinking when it comes to getting assignments done and we soon learned that American academia valued this concept. Another challenge was that, since we needed to take some of program classes online, we were also required to take a non-credit class called "blackboard". Blackboard on a computer screen is like the best joke anyone in America has ever told me. As an African international student, we were accustomed to using the physical blackboards that are traditionally stationed in the four walls of a classroom. African international students like us are used to academic requirements and expectations which include lengthy lectures without visual aids or handouts and independent learning, neither of which were the structured approach to which we were soon exposed in America. Academic challenges faced by us as an African international student stemmed from differences in educational styles, technology proficiency, and language differences relative to classroom atmosphere and facultystudent rapport.

\section{Financial pressure}

Money is the bedrock to just about any success and achievement in academia. America is home to a variety of expensive colleges and universities in the world with tuition fees ranging from $\$ 12,000$ a year, to any maximum price depending on the type and duration of degree one is seeking. According to CollegeData.com, a moderate budget for a private college in America is $\$ 47,831$ per year. Taking the tuition standard at the University of Florida as an example, an international graduate student pays $\$ 971.48$ per credit hour while graduate students who are Florida residents only need to pay $\$ 341.29$ per credit (University of Florida, 2016). With that kind of financial margin that supports American home-grown students, our biggest challenge as an African international student was to figure out how to pay for tuition and expenses before we arrived. We can remember the facial expression of father, in form of an electrical shock when we showed him our F1 student visa showing how much we need to pay for our master's degree. Our family had a plan to finance our education by selling everything that was worth selling, coupled with father's pension and retirement payment. As an African international student, having a payment plan from our home country to finance our education in the U.S is usually difficult because of the of the constant rise of the dollar exchange rate to our home currency, the economic recession iur country is currently going through and the global financial crises that hit our country's economy. From conversations we have shared with a fellow African international female student in Harrisburg, Pennsylvania, we realized that we were somewhat fortunate. Her younger sister was used as collateral by her father in order to secure money which was then pumped into her education here in America. While exchanging our life experiences with one another, we realized that the pressure and stress constantly mounted on her by her family back in Africa was synonymous to the pressure we were getting from home to get a good job. However, she has to start sending money back to Africa to pay off the price tag on her sister, and this intense personal pressure is enough of a reason for her to fail some of her courses in school.

Home grown students better known as local students have the privilege of getting government financial aid, a jaw dropping leisure African international students like me don't get to enjoy. With different forms of a makeshift plan in place to pay our tuition by our parents, we still always find ourselves in trouble of being unable to fully pay for our tuition due to the alarming exchange dollar-naira rate, deflation in our home currency and economy recession going on in our country. In addition to our academic financial challenges is the hefty cost of health insurance which was made mandatory by law for everyone living in America - including African international students. With financial pressure on mind, concentrating on academics and school programs always seems difficult. 


\section{Language}

When students from different diverse cultures are grouped together in a foreign country like America with cultural customs and traditions different from their own, communication challenges are bound to emerge. In our experience, language is one of the major challenges we face in our day to day academic life. On many occasions, we have been faced with difficulties of not being able to express ourselves properly in classes because some local students and academic instructors deemed me and other African students to have "strong accent". This experience is not uncommon as we learned a book written by American talk show host Trevor Noah titled "Born a Crime". In his book, he described accent as "speaking other people's language (like English or French) with one's own cultural rules and norms". Some African students currently studying in America studied all through their life in francophone language while some studied in Arabic language. We have seen African students from both francophone and Arabic countries struggle to communicate in English in classes because English language appears to them as a different and new language. It is true that America speaks the English language, but not the type of English we grew up using as a teaching-learning tool in our academic curriculum. Since Nigeria was colonized by Great Britain, we grew up learning through the British curriculum which was formalized in British English. Sometimes when we speak in class, pronouncing one thing often sounds different or portrays a different meaning to cohort colleague. Dr. Ferguson while addressing cohort reckons that we as humans write in the same way we talk and think. This indicates that whenever we compose our articles or assignments, most times we fall back to reflect on ideas from what we used to in our culture which can be totally different here in America and this issue sometimes causes problems in the way we express ourselves in writings and presentations. We have also seen our spellings and grammatical compositions are often harshly penalized in most cases by some instructors when we submit our research papers.

\section{Climatic change and living condition}

Climate and adapting to new living condition in America is another academic challenge for us as an African international student because of varied time zones and weather conditions from our home country. States in America itself have a series of different time zones ranging from one state to another. A good example is the time difference between Alaska and Pennsylvania; two different states in the same country but they have a different time zone, weather and climatic conditions. In our experience as an African student studying in America, we had a tough time readjusting to the sun's rising and setting, and this creates feelings of disorientation, confusion, and at times spiritual displacement. Acclimating to the American climatic and living conditions took about one year and to some other African international students, it may take more time. With four different seasons in a state like Pennsylvania, namely; winter, spring, summer and fall, it is very challenging for me being an African student from a climate with little variation, to get accustom to appropriate clothing. We always keep exchange rates in mind when making purchases for clothing and with seasons constantly changing, buying the proper clothing to wear sometimes seems difficult.

\section{Teaching-learning culture}

As an African international student, we did experience troubles in classes when we first arrived in America due to the difference in the teaching-learning culture. Cultural differences in the teaching-learning process present very real personal and professional challenges in academics. American culture of the teaching-learning process demands classroom discussion and participation which always makes language and pronunciation issues an immediate problem for us. Because of the language limitations, it is not easy for me to fully understand what the professors say or what the professors want, not to mention participating in class discussions. This also indirectly increases the workload burden on us. For example, if an American student can finish a book in an hour, an African international student who does not speak English at home may have to use several more hours to finish. Nevertheless, it is not only just a matter of language proficiency for us, our intellectual and emotional abilities are also put to test as a result of the change in our study habits to accommodate the new American teaching-learning process. Because of the dynamic difference in the teaching-learning culture here in America compared to what we was used to, it is easy for us to get depressed when we could no longer keep the grades we was used to achieving back in our home country.

In addition, the culture of education in America differs from one African country to another. For example, universities in the United States are more focused on class participation than our country Nigeria. The teaching-learning process for some African international students like us is usually a one-way monologue interaction between the teacher and the students due to the culture we grew up in that forbids African children talking back to their elders unless they are given permission to do so. This culture of teaching-learning process is totally different to the teaching-learning style in the United States. The educational approach in the United States always looked strange and unfamiliar to us because we was accustomed to seeing the teacher doing more of the talking through instructions and we expected more guidance and help from teachers.

\section{Social challenges}

Stereotyping and segregation: Our personal academic experience has led us to believe Traore that "negative stereotypes about Africa abound in American schools and in the media, making it virtually impossible for newly arrived African students, whether immigrants or refugees, to accomplish their goals of getting a quality education. Some home-grown students in America see Africa as one giant country, rather than a continent, where we all live together and somehow know each other. To date, it still surprises us to see some college students of some institutions in Harrisburg, Pennsylvania asking us if we travel around in Africa using tree vines or if we have cars at all in Africa. It was a shocking moment for us when a college student asked us if we eat bananas and fruits every day in Africa. Questions like this show that some people in America have little knowledge or are clueless about the worlds' second oldest continent.

As an African student, we arrived in America with the vibrant hope and expectations that our American education would surpass our dreams because we believe education is the only hope and way out of poverty. Many African international students we know believe that the only way to secure the best of education and better life is to come to America; a country we presume knows everything - only to get here and discover that most Americans especially the students we interact with daily in our different educational institutions know little or nothing about Africa or Africans. In our experience shared with a fellow African international student from Cameroon, we realized from our shared experience included similar stereotypes. Topics like the movie Lion King, a desert safari, Tarzan swinging by vines in the jungle, wild animals like lions, and starving people are what his entire American course mates could talk about when he asked them what they know about Africa. Stereotyping is fast becoming a major social challenge for African international students studying in America. 


\section{Racial discrimination}

Racism was and still is a challenge for us as an African student studying in America. As an African international student, growing up among children of the same skin color as ours was simply a normal way of life. Children with light skin color in Nigeria, that speak the same language as we do, are regarded as Albinos and these light skinned children are very rare. As a kid, we usually made fun of Albinos. Coming to America as an African international student gave me a full view of how life must have been horrible for our Albino friends. We have come to understand being different from the rest of the black kids and the ways people are treated due to their skin color. Racism is a disease and should be treated as one says Trevor Noah in his Daily Show telecast on Comedy Central. In America, racial discrimination is a big issue African international student like us has to deal with every single day. The racism we have experienced by some students who make fun of us by calling series of cruel names can be depressing which in turn affects academically and socially. We still routinely get insulted by people who ask if we live in huts or trees while some assume we cannot speak English, even though we come from English-speaking country.

Racism became a bitter pill for us to swallow during the summer of 2016 when we went into mega store to get a home cooling appliance. As an African student with almost nothing to spend after paying for tuition, we was on a strict spending budget which means that trying to get the best deal on any item is constantly at the forefront of our thoughts. Before making any purchase, we always convert every dollar back to naira which is home currency. This means that we spend more time in stores walking up and down aisles looking for a product with a low price that can give the anticipated result. While taking time in the store to finalize decision on what to purchase, we noticed one of the store attendants going everywhere with us pretending like he was counting stocked items. This went on for more than thirty minutes until we finally made up mind on what to buy and made way to the cash register to pay out. After making payment at the cash register, we headed out only to see two security officers who walked up to us and demanded that they needed to verify our purchase. When we demanded to know why we were the only one picked out to be searched; he told that because they saw me on camera spending more time in an area in the store was unusual in their opinion and because the store camera cannot pick up all angles they needed to search us to make sure we didn't steal anything from the store. We had been the only African present in the store during this time and very sad for being painted as a thief just because we look and speak different. This horrible experience led me to agree with Constantine et al. that apart from Black South Africans, Black African students have on average grown up in racially homogenous societies where being Black is the norm and discrimination based on race is less likely. However, on arrival in the United States which is a predominantly white society, race then becomes a crucial factor affecting African student's ease of cultural adjustment.

\section{Separation and detachment}

African students, studying in America are involved in identity negotiation and formation based on race, class, nationality, sociopolitical and economic backgrounds. We have never had to go through the process of separation from the rest of fellow students either due to color, age or intellectual capacity. Even at the secondary level in education where students are given the opportunity to choose either going to the Science class, Business also known as Commercial class or Art class, we still take general class in English, Math and many other courses together as a single cohort.

We walked into a well-known bank in America to open an account and the bank officials demanded several forms of documentation to prove identity. Since identity theft is a common issue in America and a problem we have never had to deal with, obliged to give them our documents to open a bank account. While filling out the account opening form, we noticed a section that read "indicate if you are White, African-American, Native American, Hispanic or Latino. Since none of these adjectives applied to us, we walked to the account officer to notify them of the mistake or printing error that was on the form he gave. Not seeing an adjective that qualifies as an African made us see ourselves as unwelcome strangers in the wrong place. A feeling of being detached and being separated from others instantly filled mind. After submitting the form in expectation to have an account opened, we were told by the account officer that they cannot open an account for us because we're an international student and as an international student, they project that we will eventually return back home which will in turn make the account opening a waste of the bank's resources and time. Hearing this from someone of different color than us, automatically sums up thoughts of not been welcome.

\section{Politics and Policies}

Politics in America and their direct effect on education was not something expected as immigration issues is one of the most discussed topics today since the recent Presidential election. It is a point of pride for politicians in America that educational institutions of various kinds in the country attract more international students than any other country. Each presidential aspirant had his or her own political strategies on how different policies should be tailored. International students in America generate more than $\$ 30.5$ billion in revenue in a single calendar year, and there are usually debates regarding how educational funds should be allocated or spent. Upon arrival in America, we were on high alert as to what the next policies were going to be like, and whether it was going to be favorable or not as a result of the recently concluded presidential election. From one presidential administration to another, policies on educational and visa application process have never been stable for African international student like us.

In the past administration under President Obama, executive actions on immigration policies was made which gave room for many undocumented immigrants and many international students who benefited from H1B visa which was designed to keep international students who are academic superstar. Since it's a norm in America for international students to be booted out of the country at the completion of their degrees. The new policies on immigration created a gateway to the land of milk and honey for African international students like us who have always dream of exploiting goodness in America. With this policy put in place by the past administration, the growth of African student like us in America is gradually increasing.

With the arrival of a new president, policies in place by formal administration were wiped off the table leaving hopes of pursing our dreams dashed. When we were called into the diversity office of the college to be told about the new policies guiding immigration procedures, we knew right off that our days as an international student in America are numbered. The fear and sadness of knowing policies will constantly change and these changes are never suitable for African international students has always been strenuous for us and the stress has been a major challenge to our social and academic life.

\section{Laws, Rules and Regulations}

Upon arrival in America as an international student, we were struck by with the number of countless laws that had to obey and adhere 
to. One of the social challenges, faced as an African international student in America is that there are many laws, rules and regulations ranging from the federal, state, county and boroughs. In some African countries like where we hail from, drunk driving has never been an issue unless there is a case of an accident. If anyone should get drunk and was able to drive his or her car safely back home, the society praises and applauds the fellow because of the belief that the fellow must be good at keeping their eye on the road, confident behind wheel and an expert while under the influence of alcohol. We had this negative ideology, thoughts and damning attitude when coming to America and believed that a country that encourages drinking via different forms of alcohol commercials would be like home. But then, realized that America frowns heavily on drunk driving popularly known as DUI. It was surprising to see that one needs a doctor's prescription here to buy medications like antibiotics; a common medication that we can easily get by a road side pharmacy or chemist in our country. Also that different arms of government in America ranging from the federal level to the state level have many strict laws on cannabis (marijuana); a common plant used for medicine and healings that grows in most West African countries. Driving in America using MPH can be very strange to an African students, because we grew up using KMH (kilometer Per Hour) as a speed limit which often makes the victim of speeding tickets and traffic fines because we lack the instant conversion factor in the mind.

Upon arrival in America as an African international student, we was also shocked to learn that rules and laws differ from state to state while federal laws differ from state laws and the state laws are different from county laws. In Nigeria where we come from, the supreme rule of law and the only law that governs the affairs of all states is the federal law. We always find a confused state of mind and disorientation when trying not to break a traffic law but unintentionally break another law while driving. There are so many laws in the state of Pennsylvania alone, that many of the state residents do not even know exist. This misunderstanding of laws also extended to social norms. During recreational time at a cinema, we found laughing out loud while watching a movie scene where the "Romeo and Juliet Law" that exists in the state of Texas was mentioned. Many people around us were amused to see laughing because the only Romeo and Juliet we know about was a book written by William Shakespeare. On many occasions, many African students like have found themselves in conflicting situations whereby the state and the county laws are enforced and applied simultaneously on them depending on the law they break. In an experience shared with a fellow African student from Gambia, she expressed her concern about getting a parking ticket in her own school by her own school campus security. Her frustration was known to us because no matter how hard she tried to keep the national, state, county and district laws straight, she still had problems coping with the school laws and policies.

Given the importance of the global village, international students serve as intellectual capital and ambassadors of cultural goodwill between their host countries and their countries of origin. African international students in particular come from countries that face a myriad of political, economic, and social crises. These crises are responsible for the relative state of poverty and underdevelopment in Africa today. More importantly, these crises have had fundamental negative impacts on the state of education in our beloved continent, Africa. In order to reverse Africa's plight, it is important for the continent to have labor that is skilled academically. African international students have the potential to contribute to the economic development of Africa by improving infrastructure, technology and the educational curriculum to meet the needs of our societies.

The findings that emerged from this study of the academic and social challenges faced by an African international student reveals the numerous struggles we go through in America as a result of transitioning and the difference from the norms of the Western culture. Using our life experience as an academic tool like a lens to see into these challenges, noted that some of these challenges cut across individuals as well as the generality of the African students as suggested by Evivie [5]. The majority of many challenges faced by African international students in America are based on the following:

\section{Family pressure and transitioning process}

The families of many African international students see them as the only hope to their survival. Having such a huge responsibility at the back of our mind and knowing fully well that family had to sell all their belongings to make traveling to America a possibility was enough pressure to affect both academically and socially. The hope of an entire community, family or generation sometimes lies on the shoulders of a single African student. It is this issue more than many other challenges African international students face in America that our difficult trial was built on. The transitioning process from Africa to America is another major problem which African international students in America are faced with Traoré \& Lukens, reckons that the emotional break down some African students have to go through due to separation from their families, the feeling of home sickness and above all, the stressful immigration process that seems to never end is major threat to the academic and social survival of many African international students in America. Many African international students have never experienced the need to leave their family or leave home until it's time to travel aboard for study purposes. From personal experience, the transitioning processes cause a feeling of disorientation which will affect academics and social lifestyle. The complexity of this problem is that many African international students are not prepared to handle the different stages of transitioning to America to study which often starts with immigration processes, the long hours of flight, a new cultural identity, language, housing and difference in the teaching-learning culture from what we are used to in a classroom. As an African international student, there were many complex tensions like poverty, poor governmental leadership, wars etc. present in the communities we came from which then in turn impacted learning environment and were quite different in new transition and adjustment process.

\section{Financial problem}

Due to the financial recession plundering vast numbers of African countries, many African international self-sponsored students, do not have the financial stability to pay for tuition, housing, food, new clothing and many other things needed by an African international student to survive and cope in America. The deflation in exchange rate of many African countries currency is a constant heartache for African international student given the low value of their own home currency (naira) when exchange to American dollar. With this financial problem posing a major challenge to the academic and social life of some African international students, often the African international students look for other means of support like scholarships from academic institutions or sometimes go out of the way to the "under-table jobs" which is strictly against our immigration status. Financial challenges are the most serious challenges African international students often experience which usually result in a lot of psychological feelings of stress and uncertainty. Financial difficulties with regards to school fees, housing 
and food are 248 cited as a critical challenge for African international students [6-9].

\section{Cultural difference}

Cultural difference and adapting to the new and unstable weather conditions in America is another problem for African international students which often cause a state of disorientation and lack of concentration in class. Due to difference in the American-westernized culture and our own African culture, communication and being able to express as an African international student often turned out to be difficult because of supposed "heavy African accent". The problem with cultural difference plays a major role in African international student's social and academic lives. This cultural difference is an umbrella for these two difficulties $[10,11]$.

\section{Academic difficulties}

Due to the differences in the cultural setting so African international students, adapt to the new westernized culture in America always proof to be challenging. The cultural settings of academics i.e. the teaching-learning process structure African international student used to is blatantly different from American system of education. Teaching-Learning system of education in America engage students through classroom discussion, interaction with cohort, presentation of questions and critical thinking; a system of education seen by African international students as challenging the authority of the instructor.

\section{Social difficulties}

African international students have seen our African blossoming and flamboyant social life style fade away upon arriving in America due to numerous laws ranging from federal government, state government, county and borough. Unlike African countries where laws are unified and remains almost the same from Federal government to the state and down to different local province, but this is totally different in America. America is home to thousands of laws, rules and policies which many African international students often ignorantly go against. Ignorance is not an excuse in the court of law; this means that once African student breaks any law either intentionally or ignorantly, they are compelled to face the penalties which then result into emotional and psychological disorientation to focus on their primary purpose in America [12]. Evivie suggested that while some African international students are trying to abide by some laws, they find themselves breaking another law unintentionally either within their community or school settings which then result to lack of concentration and zeal to explore their society.

\section{Conclusion and Recommendation}

Some of the challenges African international students face in America include but are not limited to be racism, constant change in immigration policies, stereotyping, and adapting to a new educational system. This can be reduced or limited if academic institutions giving out admissions to African international students can help create a supportive system that will be in place to give help to international students before they are in need. For African students coming into America, a detailed orientation program should be put in place that can help educate and integrate them into the new environment and the community they are coming into. This orientation should cover broad social issues that we strongly believe if had definitely helped to reduce many of the social challenges faced in America as an African international student issues like drunk driving, public indecency, anger control, sexual harassment and many socially tense issues should be communicated to African students that grew up in a continent that saw these issues as normal. Not only that, academic institutions should be more student oriented rather than policy oriented as many academic institutions in America are quick to drop student's academic courses or kick African international students off campus over financial related issues relating to tuition [13]. Instead, a form of financial aid, grant or financial support program should be put in place to lend a helping hand to students who have proven to deserve either via academic merit or other measures in place to determine eligibility.

Hopefully these experiences and this research can aid both students and academia in understanding the challenges they will face $[14,15]$.

\section{References}

1. Lee J, Rice C (2007) Welcome to America? International student perceptions of discrimination, Higher Education 53: 381-409.

2. Traoré R, Lukens RJ (2006) This isn't the America I thought l'd find: African students in the urban U.S. high school. Lanham, MD: University Press of America.

3. Traoré R (2006) Voices of African Students in America: We're not from the Jungle. Multicultural Perspectives 8: 29-34.

4. Ellis C, Tony E, Adams, Arthur PB (2011) Autoethnography: An Overview. 12: 10.

5. Evive LG (2009) Challenges Faced by African International Students at a Metropolitan Research University: A Phenomenological Case Study. ssertation, The University of North Carolina at Charlotte.

6. Blake AC (2004) The experiences and adjustment problems of African students at Delaware State University. (Doctoral dissertation Wilmington College (Delaware, 2004). Dissertation Abstracts International, 65/07, 2652.

7. Adesina JO (2006) Global trends in higher education reform: What lessons for Nigeria? Journal of Higher Education in Africa 4: 1-23.

8. Adler PS (1975) The transitional experience: An alternative view of culture shock. J HUMANIST PSYCHOL 15: 13-23.

9. Sam DP, Vedder E, Ward C (2006) Psychological and sociocultural adjustment in Immigrant Youth in Cultural Transition: Acculturation, Identity, and Adjustment Across National Contexts, J. W. Berry, J. Phinney, and D. Sam, Eds., pp. 117142, Lawrence Erlbaum, Hillsdale, NJ, USA, 2006.

10. Oberg K (1960) Cultural shock: Adjustment to new cultural environments Missiology: An International Review 7: 177-182.

11. Obiakor FE, Afolayan MO (2007) African immigrant families in the United States: Surviving the sociocultural tide. The Family Journal 15: 265-270.

12. Omotosho SA (1998) Becoming a stranger: The experience of African students' transformation in a baccalaureate school of nursing. (Doctoral dissertation University of Maryland, Baltimore, 1998). Dissertation Abstracts International, 59/07, 2327

13. Open Doors (2008) Report on International Education Exchange 2008 [Electronic version]. Retrieved from http://opendoors.iienetwork.org/

14. Osso JMR (2017) The international student experience: an auto-ethnographic study of international students at Ball State University.

15. Patton MQ (2015) Qualitative research and evaluation methods: integrating theory and practice: the definitive text of qualitative inquiry frameworks and options. Thousand Oaks, SAGE Publications, Inc., USA. 